This is the final peer-reviewed accepted manuscript of:

Amedeo A. Raschieri, The fragments of Republican orators in Quintilian's Institutio oratoria, in C. Gray, A. Balbo, R.M.A. Marshall, C.E.W. Steel (eds.), Reading Republican Oratory: Reconstructions, Contexts, Receptions, Oxford, Oxford University Press, 2018, pp. 77-93.

The final published version is available online at:

https://oxford.universitypressscholarship.com/view/10.1093/oso/9780198788

201.001.0001/oso-9780198788201-chapter-6

Rights / License:

The terms and conditions for the reuse of this version of the manuscript are specified in the publishing policy. For all terms of use and more information see the publisher's website. 


\section{THE FRAGMENTS OF REPUBLICAN ORATORS IN QUINTILIAN'S INSTITUTIO ORATORIA}

\section{AMEDEO RASCHIERI}

The Spanish rhetorician Quintilian (c. AD 35-c. 100) studied in Rome and, after moving back home for a few years, returned to the capital in the wake of Galba (AD 68). Here, he taught Latin rhetoric for two decades, enjoying the financial support of Vespasian. After his retirement from teaching, he wrote the twelve books of the Institutio oratoria, a work that discusses all the technical aspects of rhetoric but provides, above all, an image of the perfect orator in light of Cicero's teaching. ${ }^{1}$ Quintilian's work makes wide use of the orators of the Roman Republic: besides Cicero, the rhetorician mentions twenty-nine orators, from Appius Claudius Caecus to M. Valerius Messala Corvinus, providing more than a hundred testimonia and fragments. Quintilian deals extensively with such writers in his tenth book, in which he constructs our most extensive example of a Latin literary canon (including both poetry and prose), closely connecting this with corresponding Greek authors. ${ }^{2}$ The largest numbers of mentions are reserved for more recent Republican orators, particularly M. Caelius Rufus, C. Asinius Pollio, and M. Valerius Messala Corvinus, who will receive special attention in this study.

First, we must investigate some essential features of these quotations, the ways they are made and the functions they perform in Quintilian's work. Building on this analysis, this chapter will explore whether the author's knowledge of the Republican orators is direct or indirect, that is to say, whether he has read the works cited or if these are known through intermediary sources. In some cases, it is possible to identify the overriding grammatical, rhetorical, historical, or literary concerns that underlie Quintilian's choice of quotation. The reasons for the different numbers of quotations for each author will also be investigated, as will the extent to which, according to Quintilian, the reading of the Republican orators was

\footnotetext{
${ }^{1}$ See: López 2007; Galand-Hallyn 2010; Kraus 2014.

2 In Latin literature, we find a similar list of Greek and Roman authors in Velleius Paterculus' literary excursus (Vell. Pat. 1.5, 1.7, 1.16-18, 2. 9, 36), and in Greek literature, in the lists drawn up by Dionyius of Halicarnassus

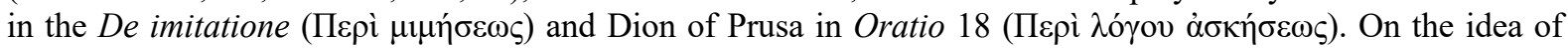
the canon in ancient literature, see Schwindt 2000; Citroni 2003; Hutchinson 2013. For Velleius Paterculus: Della Corte 1937; Gustin 1944; Santini 1970; Noé 1982; Schmitzer 2000: 72-100. For Quintilian's literary canon: Tavernini 1953; Cova 1990; Citroni 2004, 2005. For the connections between Dionysius of Halicarnassus and Quintilian: Varganova 2012.
} 
useful for the education of his contemporary ruling class. It is hoped that this analysis will not only provide a better understanding of some key features of the Institutio oratoria, but will also deepen our appreciation of the ways in which, and reasons for which, the works of the Republican orators were preserved, read, and reused in Rome during the Imperial period. ${ }^{3}$

From an extensive survey of the Institutio oratoria, ${ }^{4}$ it is noticeable that Quintilian mentions twenty-eight orators of the Republican period for a total of 108 loci, either testimonia or fragments. In eight cases, we find a single quotation (Ap. Claudius Caecus, L. Licinius Crassus, L. Licinius Lucullus, Hortensia, T. Labienus, C. Vibius Pansa, A. Hirtius, L. Sempronius Atratinus); eight times, we have two references to each author (C. Laelius Sapiens, P. Cornelius Scipio Aemilianus, M. Antonius, C. Iulius L. f. Caesar Strabo, C. Scribonius Curio pater, Cn. Pompeius Magnus, M. Porcius Cato minor, P. Cornelius Dolabella); and in four cases, we find three (Ti. Sempronius Gracchus, Q. Hortensius Hortalus, C. Iulius Caesar, M. Calidius). In addition to the orators M. Caelius Rufus (cited on thirteen occasions), C. Asinius Pollio (nineteen), and M. Valerius Messala Corvinus (ten), who, as mentioned above, will be the object of detailed analysis, other individuals cited with relative frequency are, in chronological order, M. Porcius Cato (eight occasions), Ser. Sulpicius Rufus (four), M. Iunius Brutus (six), Q. Aelius L. f. Tubero (four), and C. Licinius Macer Calvus (eight). In general, therefore, we can see that the number of references does not depend on the chronology of the orators, but remains fairly infrequent for most individuals, with the exceptions of M. Porcius Cato and M. Iunius Brutus, and increases significantly for some more recent authors. If we look at the distribution of these citations among the twelve books of the Institutio oratoria ${ }^{5}$ on the other hand, it is possible to distinguish three levels: a low level with 2-4 quotes (Books 7, 2, 3, 4, 5), a medium with 7-12 quotes (Books 8, 11, 9, 12) and a high level with 15-22 quotes (Books 1, 10, 12).

\section{AN ANALYSIS ACCORDING TO THE BOOKS}

It is worth beginning the analysis from this last point and conducting an in-depth study of the ways in which orators are cited in the books that contain the greatest number of quotations: the first, the tenth, and the twelfth. For example, in the first book of the Institutio oratoria, Malcovati identifies fifteen fragments of ten orators contained in eight sections. This book is

\footnotetext{
${ }^{3} O R F^{4}$ is used as a starting point for my analysis, though questions of selection and textual delimitation of fragments cannot be investigated in detail here.

${ }^{4}$ See in the Appendix Table 1.

${ }^{5}$ See in the Appendix Table 2.
} 
dedicated to the problem of elementary teaching; in particular, it deals with the first stages of a child's education, including the questions of whether private education or the school is preferable, and of how to recognise and develop natural talent. In this book, Quintilian also touches on the teaching of grammar, particularly the tasks of the grammarian. Furthermore, he offers a solution to the question of whether it is necessary for the orator to be educated in general culture, especially in music and mathematics. Finally, Quintilian gives advice on educating children in pronunciation and delivery, and wonders whether it is possible to learn different disciplines during childhood.

In this book, the most frequently cited authors are M. Caecilius Rufus (ORF 162 F28, 37, 38), C. Asinius Pollio (ORF $174 \mathrm{~F} 8,42)$, and M. Valerius Messala Corvinus (ORF 176 F5, 22, 24). In section 1.1.6, the author stresses the importance of a family's culture in the education of children and gives prominence to women as well as men. He mentions Cornelia (mother of the Gracchi and famous for her collection of letters), ${ }^{6}$ Laelia (whose eloquence was comparable to that of her father C. Laelius), and Hortensia (daughter of Hortensius Hortalus and well-known for a speech that was still read in Quintilian's times). ${ }^{7}$ The other quotations are related to language issues in a more or less direct way. In section 1.5.12, regarding linguistic barbarisms, Quintilian mentions the remarks of Hortensius against Tinga from Piacentia, who is also mentioned in Cicero's Brutus (172). A little later in the same chapter (1.5.61), he discusses morphological matters (Greek names in the masculine nominative), with examples tracked down (legimus) in Caelius, Messala, and Cicero. In the following chapter (1.6.29), Quintilian mentions the use of etymology by Caelius, who, to prove that he was a frugi man, said that frugalitas was derived from fructuosus ('fruitful'). In a slightly later section (1.6.42), Quintilian reflects on the relationship between authority and linguistic use, and gives some examples of words that would not be acceptable in his day but were used by Cato, Pollio, Messala, Caelius, and Calvus. In this case, the author shows his historical and linguistic sensibility, and concludes: quae nec ipsi iam dicerent. ${ }^{8}$

In the following chapter (1.7.25), Quintilian explains some phonetic transformations, in particular, the change of uortices and uorsus (and similar forms) into uertices and uersus, an innovation that, according to tradition (dicitur), was introduced by Scipio Aemilianus. At the end of the chapter (1.7.34-5), Quintilian states that grammatical topics are worthy of the

\footnotetext{
${ }^{6}$ See Hallett's paper in this volume.

${ }^{7}$ Quint. Inst. 1.1.6: Hortensiae Q. filiae oratio apud triumuiros habita legitur non tantum in sexus honorem ('the speech delivered before the triumvirs by Hortensia, the daughter of Quintus Hortensius, is still read - and not just because it is by a woman'). Quintilian's text and translation are by Russell 2001.

8 'They would not use these words nowadays themselves'.
} 
great orators, as demonstrated by the treatises of Cicero, Caesar, and Messala, although it is necessary to have a certain balance when dealing with them (non obstant hae disciplinae per illas euntibus, sed circa illas haerentibus). ${ }^{9}$ In the first book, there is one last mention of the orators of the Republican period in chapter eight (1.8.10-11), when, in addition to Cicero, Quintilian cites Asinius 'and others nearest to their times' (et ceteros qui sunt proximi) because they used the old poets (Ennius, Accius, Pacuvius, Lucilius, Terentius, Cecilius, and others) 'to support their cases or to adorn their eloquence' (ad fidem causarum uel ad ornamentum eloquentiae).

In summary, in the first book, Quintilian highlights the importance of family culture for children's education and, in particular, the women's role in this context. Moreover, he points out some linguistic issues through examples taken from orators. In these cases, he was, in all probability, able to base his discussion on a consolidated grammatical tradition, since he reports isolated passages and individual words. In any case, he follows the example of earlier orators who paid attention to grammatical issues. However, he demonstrates a prudent and balanced attitude and moves away from the excesses of some of his predecessors. Finally, since the grammarian's work consists of reading, explaining. and commenting on poetry, Quintilian emphasises the link between the teaching of grammar and rhetoric when he says that the orators of the past often cited verses by poets in their speeches.

A great number of fragments are extracted from the tenth book of the Institutio oratoria, which presents a survey of literary genres and judgements on the most important authors, along with a discussion of the role of imitation in the formation of oratorical style. In the tenth book, Quintilian deals with oratorical aptitude and presents a list of authors and works that the orator should read to improve his competence. Then he discusses the problem of imitation and explains how to write and correct works. He also presents writing exercises, explores the topic of reflection, which is preliminary to inuentio, and closes the book with advice on how to acquire and maintain improvisational skills.

In Malcovati's edition, there are twenty-one fragments from ten orators, which are found in eleven paragraphs of the tenth book. The most frequently named are Ser. Sulpicius Rufus $\left(O R F^{4} 118 \mathrm{~F} 3,4,7\right)$, C. Iulius Caesar $\left(O R F^{4} 121 \mathrm{~F} 4,5\right)$, M. Iunius Brutus $\left(O R F^{4} 158\right.$

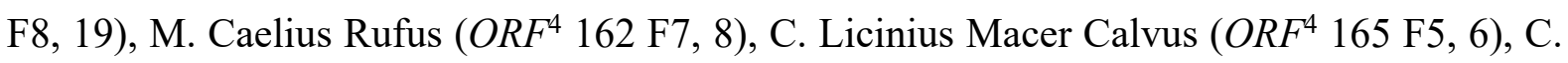
Asinius Pollio (ORF 174 F4, 5, 6, 36), and M. Valerius Messala Corvinus (ORF 176 F7, 12, 21). The first set of fragments (10.1.22-3) concerns the usefulness of reading, whenever

\footnotetext{
9 'These studies are no obstacle if they are taken as a stage to pass through, but only if you get stuck in them'.
} 
possible, 'the pleadings on both sides' (quotiens continget, utrimque habitas legere actiones), and as examples Quintilian presents Demosthenes and Aeschines, Servius Sulpicius and Messala (for and against Aufidia), and Pollio and Cassius (in the prosecution against Asprenas). Secondly, he mentions some works that have a lesser rhetorical value than those of their opponents, such as Tubero's speech against Ligarius and Hortensius in defence of Verres, both unfavourably compared to the speeches of Cicero. Thirdly, he cites some cases in which we have different speeches in favour of the same party: Calidius who 'spoke on Cicero's house' (de domo Ciceronis dixit), Brutus who 'wrote a practice speech in defence of Milo' (pro Milone orationem . . exercitationis gratia scripsit), and Pollio and Messala who 'defended the same clients' (defenderunt eosdem).

Within the section on judgements concerning Roman orators (10.1.105-22), after a lengthy section devoted to Cicero, Quintilian focuses the discussion of the central paragraphs on orators of the Republican period (10.1.113-16): Asinius Pollio and Messala (113), Gaius Caesar (114), Caelius and Calvus (115), and Servius Sulpicius (116). As usual in this literary excursus, Quintilian expresses positive judgements on these orators and synthesizes their characteristics into effective and concise descriptions. ${ }^{10}$ Then, in the section dedicated to Roman writers of philosophy (10.1.123), immediately after Cicero, Quintilian mentions Brutus, who, from his point of view, was better at producing philosophical than oratorical works (multoque quam in orationibus praestantior).

In the second chapter, the opinions expressed above are taken up in a more concise way and are connected to the problem of imitation in a discussion of bad emulative practices (10.2.17). Quintilian, for example, cites Pollio (tristes ac ieiuni Pollionem aemulantur). ${ }^{11} \mathrm{~A}$

\footnotetext{
${ }^{10}$ Asinius Pollio: multa in Asinio Pollione inuentio, summa diligentia, adeo ut quibusdam etiam nimia uideatur, et consilii et animi satis ('Asinius Pollio had much power of Invention, great precision- too much, as some think-, and adequate strategic sense and spirit').

Messala: at Messala nitidus et candidus et quadam modo praeferens in dicendo nobilitatem suam, uiribus minor ('Messala, on the other hand, is polished and transparent, and somehow displays his aristocratic qualities in his speech; but he lacks strength').

Julius Caesar: tanta in eo uis est, id acumen, ea concitatio, ut illum eodem animo dixisse quo bellauit appareat; exornat tamen haec omnia mira sermonis, cuius proprie studiosus fuit, elegantia ('He has the force, the shrewdness, the drive - you can see that he spoke with the same spirit as he waged war-but he dressed all this up in a wonderful elegance of language, of which he made a special study').

Caelius: multum ingenii in Caelio et praecipue in accusando multa urbanitas, dignusque uir cui et mens melior et uita longior contigisset ('Caelius had much talent, and a notable wit, especially in prosecuting; he deserved a wiser mind and a longer life').

Calvus: est et sancta et grauis oratio et castigata et frequenter uehemens quoque. imitator autem est Atticorum, fecitque illi properata mors iniuriam ('His style was solemn, serious, and chaste, often also energetic. He was an imitator of the Attic writers, and his untimely death did his reputation an injury').

Servius Sulpicius: insignem non inmerito famam tribus orationibus meruit (he 'deservedly won fame with his three speeches').

11 'The dreary and jejune are rivals of Pollio'.
} 
little later (10.2.25), he recommends the imitation of a variety of models such as 'Caesar's force, Caelius' asperity, Pollio's precision, or Calvus' good judgement'. ${ }^{12}$ Concerning the usefulness of translation from Greek into Latin for oratorical improvement (10.5.2), in addition to naming Cicero, Quintilian mentions its frequent use by Messala, a technique which reached its peak of excellence with the Latin translation of Hyperides' speech in defence of Phryne. We find one last mention of the orators of the Republican period in this book when Quintilian writes about the relationship between the written parts (especially openings) and improvised parts of speeches (10.7.30). In this case, in addition to Cicero, Quintilian's attention is focused on a collection of works by Servius Sulpicius: several volumes of notes and three speeches. The uniqueness of his case leads the author to state that these notes 'are so complete that they seem to me to have been composed by the orator himself for the benefit of the posterity'. ${ }^{13}$

In this book, Quintilian also suggests reading counter-posed speeches and those for the same party. Thus, we have the proof that these works were still preserved and read. Moreover, in some cases, the author places Roman orators on the same level as the Greeks, who were, in general, more famous. Quintilian probably relies on an established rhetorical tradition for the judgements passed on Roman orators, which rely in their turn on similar opinions once passed on Greek writers as a model. Finally, the link between the Roman orators and the problem of imitation is important; to guide students of rhetoric in this imitation/emulation process, Quintilian labels the authors according to their stylistic characteristics. In this way, he pays close attention to educational needs, as we can see from his discussion of translation exercises from Greek into Latin and the debate concerning the relationship between writing and improvisation.

The twelfth book contains the largest number of references to the orators of the Republican period: Malcovati's edition identifies 20 fragments related to 15 orators, taken from 8 sections of this book. The book is devoted to the characteristics of a good orator. First, Quintilian says that the orator must be an honest man, know the main elements of morality and be familiar not only with civil law but also with history. Then he explains the principal tools of the art of oratory and offers some advice on the appropriate time to start acting in trials, on what the orator should observe before accepting a case, and on preparing and delivering his speech. Finally, the book ends with a consideration of speaking style.

\footnotetext{
12 vim Caesaris, asperitatem Caeli, diligentiam Pollionis, iudicium Calui.

${ }^{13}$ ita sunt exacti ut ab ipso mihi in memoriam posteritatis uideantur esse compositi.
} 
In this book, the most cited orators are M. Porcius Cato the elder $\left(O R F^{4} 8 \mathrm{~F} 6,7,8\right)$, C. Iulius Caesar $\left(O R F^{4} 121\right.$ F5, 16), C. Licinius Macer Calvus $\left(O R F^{4} 165\right.$ F7, 14), and C. Asinius Pollio $\left(O R F^{4} 174\right.$ F7, 15). The first quotation of the book refers to Cato (12.3.9), who is defined as an excellent orator and an expert on the law (cum in dicendo praestantissimus, tum iuris idem fuit peritissimus). Then, within the discussion of the most suitable age to begin the practice of oratory, Quintilian mentions the cases of the young Calvus, Caesar, and Pollio (12.6.1). ${ }^{14}$ Shortly afterwards, at 12.7.3-4, he mentions Hortensius, the Luculli, Sulpicius, Cicero, Caesar, and Cato as examples of young men of high social class (clari iuuenes) who accused wicked citizens and, in this way, distinguished themselves for their devotion to the state and moral rectitude. ${ }^{15}$

Quintilian devotes ample space to a historical and literary excursus on the styles of oratory (12.10.10-11), which are divided into four parts. The first group consists of the kinds of eloquence which are more archaic and crude but which have great intellectual force (horridiora, alioqui magnam iam ingenii uim prae se ferentia), represented by Gaius Laelius, Scipio Aemilianus, Cato the Censor, and the Gracchi. An intermediate position is occupied by the works of L. Crassus and Q. Hortensius Hortalus, followed by the most remarkable period of Roman oratory (efflorescat . . . oratorum ingens prouentus). The orators of this period are listed along with the distinctive features already described in the tenth book: the force of Caesar (uim), the natural talent of Caelius Rufus (indolem), the fineness of Marcus Calidius (subtilitatem), the care of Asinius Pollio (diligentiam), the dignity of Messala Corvinus (dignitatem), the purity of Calvus (sanctitatem), the severity of Brutus (grauitatem), the acumen of Sulpicius Rufus (acumen), and the harshness of Cassius Severus (acerbitatem). Then, Quintilian presents the orators that he personally knew but who are outside the present discussion: Seneca, Julius Africanus, Domitius Afer, Vibius Crispus, Galerius Trachalus, and Julius Secundus.

Other judgements are also offered later (12.10.39), where the quality of Cicero- the fact that he was 'acute, precise, and not too lofty in his private speeches' (in priuatis et acutus et distinctus et non super modum elatus) — is likewise attributed to Marcus Calidius. Scipio, Laelius, and Cato are called 'the Roman equivalent of the Attic orators' (Attici Romanorum) because of their style of rhetoric. In the final chapter of the book, in three sections, Quintilian refers again to the Roman orators. In one case (12.11.6), in order to demonstrate that teaching

${ }^{14}$ Caluus, Caesar, Pollio multum ante quaestoriam omnes aetatem grauissima iudicia susceperint ('Calvus, Caesar, and Pollio all undertook important cases before they were old enough to hold the quaestorship').

15 creditique sunt etiam clari iuuenes obsidem rei publicae dare malorum ciuium accusationem ('and young men of distinction have been held to give a pledge to society in the form of the prosecution of bad citizens'). 
is an honourable activity, Cicero is mentioned as the master of Caelius, Pansa, Hirtius, and Dolabella (sic ad se Caelium deductum a patre Cicero profitetur, sic Pansam, Hirtium, Dolabellam ad morem praeceptoris exercuit cotidie dicens audiensque). In a second case (12.11.23), Cato the Censor is defined as a great general, philosopher, orator, historian, and expert on law and agriculture (idem summus imperator, idem sapiens, idem orator, idem historiae conditor, idem iuris, idem rerum rusticarum peritissimus fuit). In the last case (12.11.28), along with the concluding exhortations to the future orators, Quintilian says that it is possible to achieve fame despite the simultaneous presence of more distinguished personalities. To prove this statement, he presents the examples of Pollio and Messala, who gained prestige in life and glory with posterity, despite plying their forensic work 'when Cicero occupied the commanding heights of eloquence' (iam Cicerone arcem eloquentiae tenente).

In the twelfth book, Quintilian uses the examples of ancient Roman orators, from Cato on, to build up the image of the ideal orator, particularly in knowledge of the law, youth, and moral rectitude. Furthermore, he again summarizes the characteristics of individual orators, already outlined in the tenth book, to define the different oratorical styles, arranged in chronological order. In this case, his literary and historical focus has a strong educational purpose, also demonstrated by the constant comparisons with Cicero's works and the Greek tradition. Finally, the examples of the orators of the past allow him to define the main features of rhetorical teaching, which is an honourable and complex task and requires many skills. Reassurance is provided to the young orator, who can achieve success despite other authoritative competitors.

\section{AN ANALYSIS ACCORDING TO THE ORATORS}

After developing the analysis according to the different books of the Institutio oratoria, it is worthwhile to move on to the three orators of the Republican period that, after Cicero, are given the most space in Quintilian's work: M. Caelius Rufus, C. Asinius Pollio, and M. Valerius Messala Corvinus. Malcovati found thirteen reference-worthy passages relating to M. Caelius Rufus in Quintilian, four of which $\left(O R F^{4} 162\right.$ F6-9) are inserted among the testimonia and concern the characteristics of his rhetorical style. ${ }^{16}$ To express the fact that Caelius 'performed better in prosecution than in defence' (melius obicientem crimina quam

\footnotetext{
${ }^{16}$ About M. Caelius Rufus see: Madsen 1981.
} 
defendentem), Cicero used a military allegory and claimed that he had a good right hand (the one which held the sword) and a bad left (the one which held the shield): bonam dextram, malam sinistram habere dicebat (6.3.69). ${ }^{17}$ The following fragments have already been mentioned in connection with the books 10 and 12. In these books, Quintilian mentions the positive characteristics of Caelius' personality and rhetorical style, in particular, his considerable talent and great grace-compensation for his weakness of spirit and short life (10.1.115) - , his vehemence (10.2.25) and, once again, his natural talent (12.10.11).

Moreover, Quintilian mentions two of Caelius' speeches: In C. Antonium (59 BC) and Pro se de ui contra L. Sempronium Atratinum (56 BC). From the first speech, which is also known through Cicero's Pro Caelio $(15,74,78)$ and which probably focused on an allegation of bribery or treason, we read a long direct quotation $\left(O R F^{4} 162 \mathrm{~F} 17\right)$ in the fourth book of the Institutio oratoria (4.2.123-24). ${ }^{18}$ Quintilian praises this section for the effective description (incredibilis rerum imago) of the proconsul Gaius Antonius Hybrida, drunk and surrounded by prostitutes, surprised by the arrival of the enemy. We find a second short fragment (F18) taken from the same speech in Quintilian's ninth book (9.3.58) in a section concerned with ellipsis, a figure based on the omission of a word that is easily understood

\footnotetext{
${ }^{17}$ Cicero's judgement is comparable with Cic. Brut. 273: graues eius contiones aliquot fuerunt, acres accusationes tres eaeque omnes ex rei publicae contentione susceptae; defensiones, etsi illa erant in eo meliora quae dixi, non contemnendae tamen saneque tolerabiles ('He made some important public speeches and three merciless prosecutions, all of which arose out of political ambition and rivalry. His court speeches in defence of himself and others, although inferior to those which I have mentioned, were not negligible, indeed quite tolerable'). Cicero's text and translation are by Hendrickson 1939.

${ }^{18}$ See also Hendry 1994. Quint. Inst. 4.2.123-24: namque ipsum offendunt temulento sopore profligatum, totis praecordiis stertentem ructuosos spiritus geminare, praeclarasque contubernales ab omnibus spondis transuersas incubare et reliquas circum iacere passim: quae tamen exanimatae terrore, hostium aduentu percepto, excitare Antonium conabantur, nomen inclamabant, frustra a ceruicibus tollebant, blandius alia ad aurem inuocabat, uehementius etiam nonnulla feriebat; quarum cum omnium uocem tactumque noscitaret, proximae cuiusque collum amplexu petebat: neque dormire excitatus neque uigilare ebrius poterat, sed semisomno sopore inter manus centurionum concubinarumque iactabatur ('They found the man himself stretched out in a drunken stupor, snoring with all the force of his lungs, belching repeatedly, while the distinguished ladies who shared his quarters sprawled over every couch, and the other women were lying on the floor all around. Half dead with terror, and aware now of the enemy's approach, they tried to rouse up Antonius; they shouted his name, and tried in vain to hoist him up by his neck; some whispered blandishments in his ear, one or two gave him an energetic slap. He recognized all their voices and their touch, and tried to put his arms round the neck of whoever was nearest to him. He was too much aroused to sleep, and too drunk to stay awake; dazed and half asleep, he was thrown around in the arms of his centurions and his concubines').

Due to the extent of this fragment, it is possible to conduct a more detailed analysis. In particular, its descriptive effectiveness depends on structural characteristics and stylistic components. It includes three different points of view: that of those who surprise Antonius drunk and surrounded by prostitutes; that of the women, with the description of their furious reaction to the enemy's arrival; and that of Antonius with his semi-conscious behaviour. The meticulousness of this report is clear, especially in the central section dedicated to the women: when sleeping, they are divided into two groups, one on couches and one on the ground; then, when the opponents arrive, the groups became five. From a stylistic point of view, the realistic lexicon is marked (totis praecordis stertentem ructuosus spiritus geminare), as is the ironic tone (praeclarasque contubernales), the use of expressions that combine parallel and contrast (neque dormire excitatus neque uigilare ebrius), and the strong alliteration (alia ad aurem, sed semisomno sopore, centurionum concubinarumque).
} 
from the context. In his attack on Gaius Antonius, Caelius, for example, used the expression stupere gaudio Graecus, implying the verb coepit.

From the speech Contra L. Sempronium Atratinum, also known through Cicero's Pro Caelio (45) and through Suetonius (Rhet. 2), Quintilian inserts in the eleventh book (11.1.51) a large direct quotation $\left(O R F^{4} 162 \mathrm{~F} 25\right)$ as an example of congruence between the message and the context: Marcus Caelius' facial expression, tone of voice and gestures, marked by humility, match his desperate situation. ${ }^{19}$ Two more fragments (F26-7) from this speech are found in the same section of the eighth book (8.6.52-3). In these cases, Quintilian blames Caelius for using obscure allegories and riddles (allegoria quae est obscurior aenigma dicitur) and quotes two insulting expressions used against Clodia: quadrantariam Clytaemestram ('fourpenny Clytemnestra') and in triclinio coam, in cubiculo nolam ('Coa at dinner, Nola in the bedroom'). ${ }^{20}$ The last fragment (F28) of this speech concerns the use of etymological procedure with a rhetorical function (1.6.29). ${ }^{21}$ From the first book, we also have two fragments incertae sedis $(\mathrm{F} 37,38)$, which concern the use of the nominative Pelia cincinnatus ('a curly-haired Pelias') instead of Pelias cincinnatus (1.5.61) and the eccentric noun parricidatus ('parricide'), 'which is barely to be borne in Caelius' (1.6.42). ${ }^{22}$ From a speech otherwise unknown, we find mention of a funny story (F39) told by Caelius about a competition between the quaestor Decimus Laelius and his colleague to reach the province of Sicily $(6.3 .39,41) .^{23}$

For the stylistic features of Caelius Rufus, Quintilian uses material that was probably pre-selected by the scholastic tradition. Moreover, the relationship with Cicero's work is important, in particular for the selection of speeches that were considered the most important

\footnotetext{
${ }^{19}$ Quint. Inst. 11.1.51: ne cui uestrum atque etiam omnium qui ad rem agendam adsunt meus aut uultus molestior aut uox inmoderatior aliqua aut denique, quod minimum est, iactantior gestus fuisse uideatur ('I hope none of you — or any of those who have come to see this business done — will find too much offensiveness in my expression, undue violence in some word I utter, or indeed, trifling as this is, flamboyance in my gestures').

20 On these expressions see Russell 2001: 3.456 n. 75: 'spoken of Clodia, compared to Clytemnestra and attacked for her adultery and alleged murder of her husband . . .; she charges her lovers a quadrans (Plutarch, Cicero 29). Coa presumably suggests coitus, and Nola unwillingness'. See also: Verdière 1987; Stärk 2001.

${ }^{21}$ See above, p. 000.

${ }^{22}$ quod in Caelio uix tolerabile uidetur.

${ }^{23}$ narrare quae salsa sint in primis est subtile et oratorium, ut Cicero pro Cluentio narrat de Caepasio atque Fabricio aut M. Caelius de illa D. Laeli collegaeque eius in prouinciam festinantium contentione. . . et Caelius cum omnia uenustissime finxit, tum illud ultimum: 'hic subsecutus quo modo transierit, utrum rati an piscatorio nauigio, nemo sciebat: Siculi quidem, ut sunt lasciui et dicaces, aiebant in delphino sedisse et sic tanquam Ariona transuectum' ('To narrate humourous stories is a particularly subtle rhetorical move; for example, Cicero's narrative in Pro Cluentio about Caepasius and Fabricius, or Caelius' story of the quarrel between Decimus Laelius and his colleague as they both hurried off to their province. ... The whole of the picture that Caelius gives is delightful, but especially the end: "He followed; but how he crossed over, by raft or by fishing boat, nobody knew. The Sicilians, with their naughty sense of humour, said he rode on a dolphin, and so made the crossing like Arion."'). See Russell 2001: 3.82 n. 32.
} 
and worthy of being read, at least selectively. However, Quintilian demonstrates his wider knowledge of Caelius' work, as attested not only by the many fragments incertae sedis but also from the extensive quotations, only preserved by him, of the speeches In C. Antonium and Contra L. Sempronium Atratinum. Furthermore, the off-hand reference to the otherwise unknown episode of the competition among the quaestors proves that Quintilian expected his reader to have some familiarity with Caelius' speeches, and he certainly uses them as an important source for rhetorical education, comparable even to those of Cicero.

Malcovati collects nineteen references to C. Asinius Pollio in Quintilian, the most quoted orator in the Institutio oratoria. ${ }^{24}$ Five of these are listed among the testimonia (ORF 174 F4-8) and come from the first, tenth, and twelfth books. In the tenth book, we find the judgements passed on his work, which is characterised by 'much power of invention, great precision' and by 'adequate strategic sense and spirit', but which does not reach Cicero's 'polish and elegance', and so seems archaic (10.1.113). ${ }^{25}$ Despite the unfavourable comparison with Cicero, Pollio reached, in any case, 'honour enough in his lifetime' and 'fame with posterity' (12.11.28). ${ }^{26}$ As said earlier, his oratorical characteristics are interpreted with the requirements of potential imitators in mind (10.2.17); these are, however, only 'dreary and jejune' (tristes ac ieiuni). Quintilian instead exhorts his students to follow Pollio's 'precision' (diligentia, 10.2.25) and commends the use of poetic fragments in his speeches (1.8.10).

Quintilian is also the main source for four of Pollio's speeches. In the twelfth book (12.6.1) we find a brief mention of the speech In C. Porcium Catonem, which made the orator famous for his precocious forensic activity. ${ }^{27}$ Another speech, the Pro M. Aemilio Scauro, is known with certainty only from the text of Quintilian, who mentions it in the context of the main rhetorical strategy used by Pollio: in the wake of Cicero, who twice defended the father of the accused, he pointed out 'his standing, his bravery, his battle scars, his birth, and the services of his ancestors' $(6.1 .21) .{ }^{28}$ In another passage (9.2.24) we find the only direct quote

\footnotetext{
${ }^{24}$ On C. Asinius Pollio see: Zecchini 1982.

${ }^{25}$ multa . . . inuentio, summa diligentia . . . et consilii et animi satis: a nitore et iucunditate Ciceronis ita longe abest ut uideri possit saeculo prior.

${ }^{26}$ See above, p. 000.

27 Tacitus (Dial. 34.7) shows that this speech, along with others by L. Crassus, Caesar, and Calvus, was still read in his time: nono decimo aetatis anno L. Crassus C. Carbonem, uno et uicensimo Caesar Dolabellam, altero et uicensimo Asinius Pollio C. Catonem, non multum aetate antecedens Caluus Vatinium iis orationibus insecuti sunt quas hodieque cum admiratione legimus ('Lucius Crassus was in his nineteenth year when he impeached Gaius Carbo, Caesar in his twenty-first when he undertook the prosecution of Dolabella, Asinius Pollio twentyone when he attacked Gaius Cato, and Calvus not much greater in age when he prosecuted Vatinius; to this day we read with admiration the speeches they delivered on those occasions').

28 dignitas et studia fortia et susceptae bello cicatrices et nobilitas et merita maiorum.
} 
from this speech, included in a discussion of the trope of communicatio. ${ }^{29}$ Quintilian is also our only source for Pollio's Pro Liburnia: this speech is used in the ninth book of the Institutio oratoria, and was pronounced during a trial in which the orator worked with Messala Corvinus. We can read two direct quotes from this speech: one about the possibility of including fake written interventions in speeches $(9.2 .34),{ }^{30}$ and the other on ways to question a witness in order to prevent him from lying (9.2.9). ${ }^{31}$

Quintilian is our main source for the Pro Vrbiniae heredibus: ${ }^{32}$ in the Institutio oratoria, we read five fragments of this speech $\left(O R F^{4} 174 \mathrm{~F} 29-33\right)$ that are used to explain several rhetorical strategies. The first (4.1.11) concerns the prooemium, in which Asinius Pollio inserted, offensively, Labienus, 'the other side's advocate' (partis aduersae patronus), using this strategy as 'an argument for the badness of their cause' (inter argumenta causae malae). The second fragment (7.2.4) is related to 'conjecture' (coniectura) and refers to the possibility of investigating the real identity (quis sit) of one of the parties involved in the trial ('the question was whether the man who claimed the property as a son was Figulus or Sosipater'). ${ }^{33}$ A little later (7.2.26), Quintilian summarises, with an abundance of detail, the opposing reconstructions that were offered by the prosecutor (petitor) and by Asinius Pollio of the adventurous biography of Clusinius Figulus, son of Urbinia. ${ }^{34}$ The fourth fragment consists of Pollio's reproach to Labienus for the expression rebus agentibus, which was in current use in Quintilian's day (9.3.13). In the last fragment (8.3.32), among a list of

29 illis non accedo qui schema esse existimant etiam, si quid nobis ipsis dicamus inexspectatum accidisse, ut Pollio: 'nunquam fore credidi, iudices, ut reo Scauro ne quid in eius iudicio gratia ualeret precarer' ('I do not agree with those who say there is a Figure also when we claim that something unexpected has happened to ourselves: "Members of the jury," says Pollio, "I never thought it would happen that, with Scaurus as the accused, I should find myself pleading that influence should have no weight in his trial."”).

${ }^{30}$ ut dicta autem quaedam, ita scripta quoque fingi solent, quod facit Asinius pro Liburnia: 'mater mea, quae mihi cum carissima tum dulcissima fuit, quaeque mihi uixit bisque eodem die uitam dedit' et reliqua, deinde 'exheres esto' ('Writings as well as words are sometimes made up, as by Asinius in his defence of Liburnia: "My mother, who was very dear and very close to me, who lived for me and gave me life twice on the same day ..." and so on, and then: "shall have no part in my estate."”).

31 aut instandi et auferendae dissimulationis, ut Asinius: 'audisne? Furiosum, inquam, non inofficiosum testamentum reprehendimus' ('putting on pressure and stopping our opponent from pretending to misunderstand: "Do you hear me? The will we impugn is a mad will, not just an inequitable one", Asinius').

32 This speech is also mentioned at Tac. Dial. 38.2.

${ }^{33}$ Is qui tamquam filius petebat bona Figulus esset an Sosipater.

${ }^{34}$ Utraque enim pars suam expositionem habet atque eam tuetur, ut in lite Vrbiniana petitor dicit Clusinium Figulum filium Urbiniae acie uicta in qua steterat fugisse, iactatumque casibus uariis, retentum etiam a rege, tandem in Italiam ac patriam suam †marginos $\dagger$ uenisse atque ibi agnosci: Pollio contra seruisse eum Pisauri dominis duobus, medicinam factitasse, manu missum alienae se familiae uenali inmiscuisse, a se rogantem ut ei seruiret, emptum ('Both parties make and maintain their own account of the events. Thus in the case of Urbinia, the claimant alleges that Clusinius Figulus, Urbinia's son, escaped after the defeat of the army in which he had fought, underwent various adventures, was even kept prisoner by the king, and finally returned to Italy and his home among the $\uparrow$ Margini $\uparrow$ and was recognised there. Pollio, on the other hand, asserted that he had served two masters as a slave at Pisaurum, practised medicine, been manumitted, joined another slave household which was for sale, and was bought as a slave, at his own request, by Pollio'). 
neologisms coined by derivation, Quintilian mentions the word figulatum, invented by Asinius Pollio.

The last quoted speech is the Pro Nonio Asprenate (ORF 174 F36), which, as seen above, Quintilian mentions briefly in the tenth book (10.1.22) regarding the usefulness of reading speeches delivered by opposing sides (in this case, Pollio and Cassius). Lastly, we have three fragments incertae sedis (F42, 43, 44): the expression hi lodices ('these blankets'), in masculine form, attested by the orator but condemned by Quintilian (1.6.42); the direct quotation of an address by Asinius Pollio to Caesar, which is, according to Celsus, the example of 'the best type of composition' (optimam compositionem) for the proemium of a speech (9.4.132); and the word fimbriatum, which is paired with the figulatum previously noted (8.3.32).

Even in the case of Asinius Pollio, Quintilian probably exploits scholastic material for the judgements on his style. Furthermore, he explicitly states that this orator is famous in posterity. In particular, Quintilian encourages his readers to follow the best features of Pollio's style; because of Quintilian's appreciation for him, the Institutio oratoria is now the primary source for four of Pollio's speeches. In particular, according to Quintilian, reading these works will be useful for improving the structure of one's own orations and for a better understanding of certain stylistic features, figures of speech, and linguistic problems. Therefore, the large number of fragments is proportional to Quintilian's appreciation for the work of Pollio, who, again according to Quintilian, suffered from standing in Cicero's shade and, above all, for the archaic nuance of his prose.

Quintilian mentions M. Valerius Messala Corvinus ten times. Five of these are included among the testimonia in Malcovati's edition $\left(O R F^{4} 176 \mathrm{~F} 5-8\right) .{ }^{35}$ The first (1.7.35) is a reference to his books on grammar concerning individual words and letters (libellos non uerbis modo singulis sed etiam litteris). The second (4.1.8) concerns a special feature that characterises 'many of Messala's Prooemia' (pleraque Messalae prohoemia): the search for 'a certain tacit approval' (commendatio tacita) from the audience, achieved through a declaration of weakness or lack of preparation, or being no match for the talents of the opposing party (infirmos, inparatos, inpares). The third passage concerns the stylistic

\footnotetext{
${ }^{35}$ About M. Valerius Messala Corvinus see: Hanslik 1955.
} 
characteristics of the orator (10.1.113); these features are summarised in the last quotation, which focuses on Messala's 'dignity' (12.10.11). ${ }^{36}$

Quintilian explicitly mentions two speeches by Messala, the Contra Aufidiam (F1213) and the Oratio Hyperidis pro Phryne in latinum uersa (F21-2), for which the Institutio is our only source. The first, delivered in 44 or $43 \mathrm{BC}$, is cited alongside the speech of his opponent Servius Sulpicius (10.1.22), and also in a very corrupt section of the sixth book (6.1.20), which concerns an orator's potential to anticipate arguments that 'later come to be repeated by the defence' (pro reo repetentur). As mentioned earlier, Quintilian praises Messala's ability to translate Greek speeches into Latin, to the extent that he can compete with Hyperides in rewriting the defence for Phryne (10.5.2). The only surviving fragment of this speech is contained in the first book, bene fecit Euthia (1.5.61), cited for the form in $-a$ of the nominative of the Greek masculine name. Two other fragments incertae sedis are isolated words: the neuter plural gladiola ('small swords'), used by Messala and condemned by Quintilian as obsolete (1.6.42), and the neologism reatus ('accused person'), introduced by the orator and now in common use in Quintilian's day (8.3.34). ${ }^{37}$

According to Quintilian, Messala Corvinus' speeches are worthy of attention for grammatical reasons and certain stylistic characteristics, especially those relating to introductions. Furthermore, the Institutio oratoria provides relevant evidence regarding individual speeches, even if we do not find extensive quotations from these in Quintilian's work. Therefore, we do not know if the rhetorician read these texts directly or knew them through the mediation of the school tradition.

\section{CONCLUSION}

In conclusion, the analysis of quotations from orators of the Republican period in the Institutio oratoria, both in individual books and of individual authors, has highlighted several interesting features of their use in Quintilian. These orators belong firmly to the literary canon of authors that a contemporary orator must know if they wish to read and imitate the

\footnotetext{
${ }^{36}$ See above n. 10. For the stylistic judgement on Messala in comparison with Cicero see Tac. Dial. 18.2: Cicerone mitior Coruinus et dulcior et in uerbis magis elaboratus ('Corvinus again is mellower than Cicero, more engaging, and more careful in his choice of words').

37 Quaedam tamen perdurant. Nam et quae uetera nunc sunt fuerunt olim noua, et quaedam sunt in usu perquam recentia: [ut Messala primus 'reatum', 'munerarium' Augustus primus dixerunt] 'reatum' nemo ante Messalam, 'munerarium' nemo ante Augustum dixerat ('However, some words do stick. Those which are old now were new once, and some very modern words have become accepted: no one had said reatus before Messala, or munerarius before Augustus').
} 
best models. References to these authors are extremely varied, ranging from the mere mention of an orator's name or title of his work to judgements on lexical, rhetorical, or stylistic features, some short literary quotations, and even quite extensive passages, often transmitted only by the Institutio oratoria. While for many orators, especially the older ones, Quintilian's knowledge could be derived from intermediate sources, our author shows a good first-hand knowledge of many speeches, especially those of more recent orators. Quintilian often emphasises that the quoted speeches were actually read (legitur, legimus), as in the cases of Hortensia (1.1.6), Caelius, Messala, and Cicero (1.5.61). On this subject, we also have the statement of Tacitus, which testifies to the reading (legimus) of the works by L. Crassus, Asinius Pollio, Caesar and Calvus (Dial. 34.7). Moreover, Quintilian affirms in the tenth book (10.1) that the students of rhetoric must read separate speeches, and sometimes all the discourses related to the same case, even the least effective ones. The Latin rhetorician is also aware of the diverse types of texts which transmitted ancient oratorical performances: in the case of Servius Sulpicius (10.7.30) not only complete speeches are preserved but also some parts of speeches along with notes for the other sections. Despite Quintilian's recommendations, however, most of these works were soon forgotten, demonstrated by the fact that they are no longer used or even mentioned by later authorities.

Regardless of the excellence of the example provided by Cicero, often affirmed and emphasised by Quintilian (not without some criticism, at least at the level of rhetorical theory), these orators fit well into the larger educational project pursued in the Institutio oratoria. They are used as moral examples, ${ }^{38}$ as lexical, rhetorical, and stylistic examples, often accepted but sometimes forcefully rejected, but always included in more general literary, historical, and cultural frameworks. Quintilian finds continuity in the Roman oratory tradition (12.101.11): late Republican and early Imperial orators are separated for individual characteristics and divided into two groups only for chronological reasons according to the direct knowledge by Quintilian. Therefore, Quintilian's attitude toward the Roman orators is in continuity with that of Cicero's Brutus: they are the object of a stylistic and rhetorical judgment and valuable for the construction of a cultural memory which has rhetorical education as its primary purpose. Alongside the most important Greek authors, Cicero, and more recent Latin authors, Roman orators of the Republican period are fundamental models not only for contemporary orators in training, but also for those already active, part of

\footnotetext{
${ }^{38}$ See above (p. 000) for the importance of well-educated women in the pedagogical model proposed in the first book.
} 
Quintilian's emulative and anti-dogmatic vision, sensitive to new linguistic and social needs but eager to find solid roots in the past. 


\section{Appendix}

Table 1

20
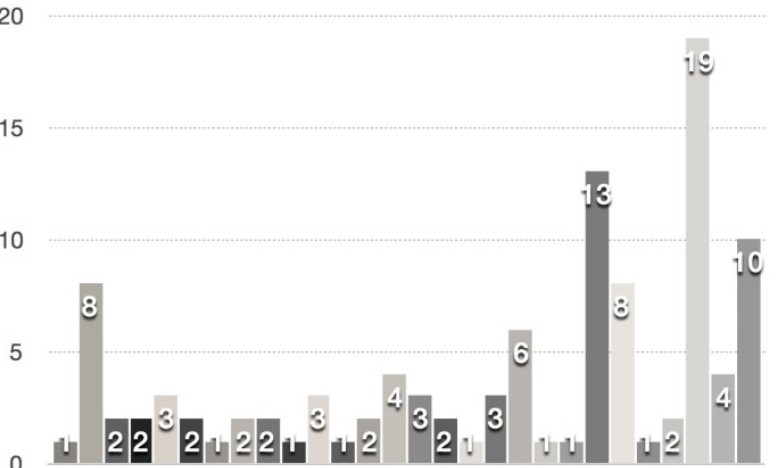

0

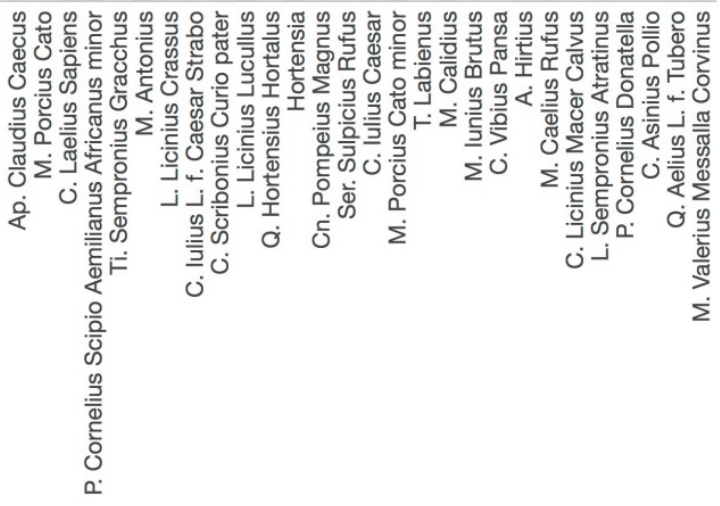

\section{ORATORS}

QUOTES

Ap. Claudius Caecus

M. Porcius Cato

C. Laelius Sapiens

P. Cornelius Scipio Aemilianus Africanus minor

Ti. Sempronius Gracchus

M. Antonius

L. Licinius Crassus

C. Iulius L. f. Caesar Strabo

C. Scribonius Curio pater

L. Licinius Lucullus

Q. Hortensius Hortalus

Hortensia

Cn. Pompeius Magnus

Ser. Sulpicius Rufus

C. Iulius Caesar

M. Porcius Cato minor

T. Labienus

M. Calidius

M. Iunius Brutus

C. Vibius Pansa

A. Hirtius

M. Caelius Rufus

C. Licinius Macer Calvus

L. Sempronius Atratinus

P. Cornelius Donatella

C. Asinius Pollio

Q. Aelius L. f. Tubero

M. Valerius Messalla Corvinus

1

8

2

2

3

2

Table 2 
22

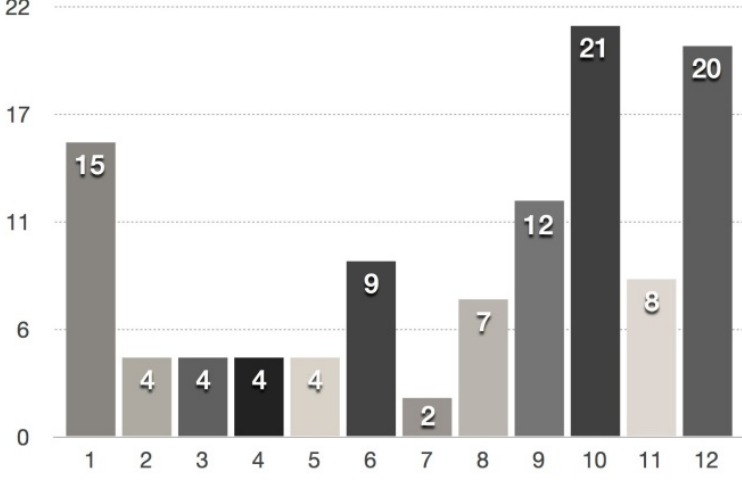

BOOKS

QUOTES

$\begin{array}{ll}1 & 15\end{array}$

$2+4$

4

5

6

7

8

10

11

12
4

4

9

2

12

20 